\title{
COST-BENEFIT ANALYSIS PEMBANGUNAN PELABUHAN PATIMBAN TERHADAP MASYARAKAT PESISIR DI KABUPATEN SUBANG
}

\author{
Somadi \\ Program Studi D4 Logistik Bisnis, Politeknik Pos Indonesia \\ email: somadi@poltekpos.ac.id
}

\begin{abstract}
Abstrak
Pelabuhan merupakan salah satu prasarana transportasi yang memiliki peran penting dalam perkembangan industri, perdagangan dan jasa serta memberikan kontribusi bagi perekonomian. Selama ini aktivitas pelabuhan di Indonesia masih didominasi di Pelabuhan Tanjung Priuk, sehingga lalu lintas di Pelabuhan Tanjung Priuk sering mengalami kepadatan dan arus lalu lintas kendaraan selalu mengalami kemacetan sehingga membuat biaya logistik menjadi tinggi. Untuk itu diperlukan pembangunan Pelabuhan Patimban. Namun dalam pembangunan Pelabuhan Patimban terdapat pro dan kontra khususnya dari masyarakat pesisir, karena akan memberikan dampak positif dan negatif bagi perekonomian masyarakat. Tujuan penelitian yaitu ingin mengetahui kelayakan pembangunan Pelabuhan Patimban dari segi ekonomi bagi masyarakat pesisir. Teknik analisis yang digunakan dalam penelitian ini menggunakan cost-benefit analysis. Berdasarkan hasil analisis jika dampak pembangunan Pelabuhan Patimban hanya berfokus pada masyarakat pesisir dan hanya bekerja menjadi TKBM, maka pembangunan tidak layak untuk dilaksanakan karena keuntungan yang dihasilkan lebih kecil dibandingkan dengan kerugian yang ditimbulkan adanya pembangunan Pelabuhan Patimban. Sedangkan kerugian adanya pembangunan Pelabuhan Patimban yaitu hilangnya penghasilan masyarakat akibat adanya penggunaan lahan darat dan reklamasi. Namun secara menyeluruh bahwa pembangunan Pelabuhan Patimban memberikan dampak besar bagi perkembangan ekonomi baik masyarakat pesisir, dan perekonomian daerah, daerah tetangga dan Indonesia.
\end{abstract}

Kata kunci: pelabuhan patimban, masyarakat pesisir, cost-benefit analysis

\begin{abstract}
The port is one of the transportation infrastructure that has an important role in the development of industry, trade and services and contributes to the economy. During this time port activities in Indonesia are still dominated at the Port of Tanjung Priuk, so that traffic at the Port of Tanjung Priuk often experiences congestion and the flow of vehicle traffic always experiences congestion which makes logistics costs high. For this reason, Patimban Port development is needed. But in the development of Patimban Port there are pros and cons, especially from coastal communities, because it will have positive and negative impacts on the community's economy. The research objective is to find out the feasibility of developing Patimban Port in terms of economy for coastal communities. The analysis technique used in this study uses cost-benefit analysis. Based on the results of the analysis if the impact of Patimban Port development only focuses on coastal communities and only works as a TKBM, the development is not feasible to be carried out because the benefits generated are smaller than the losses incurred in the construction of Patimban Port. While the loss of Patimban Port development is the loss of community income due to land use and reclamation. But overall, the development of the Patimban Port has a big impact on the economic development of both the coastal communities, and the economy of the region, neighboring regions and Indonesia.
\end{abstract}

Keywords: patimban port, coastal communities, cost-benefit analysis

\section{PENDAHULUAN}

\subsection{Latar Belakang}

Pada dasarnya pelabuhan mempunyai peran penting dalam perkembangan industri, perdagangan dan jasa. Hal ini disebabkan karena pelabuhan merupakan salah satu prasarana transportasi yang cukup vital bagi sebuah negara, terutama pada negara maritim seperti Indonesia. Pelabuhan juga merupakan 
salah satu usaha yang dapat memberikan kontribusi bagi perekonomian baik nasional maupun daerah, karena dengan adanya pelabuhan maka kegiatan ekonomi suatu negara atau daerah akan dapat menjadi lebih lancar. Menurut Triatmodjo dalam Zulkifli (2017), berdasarkan pada fakta yang ada pada beberapa negara, barang-barang ekspor impor sebagian besar dikirim melalui jalur laut membutuhkan pelabuhan atau tempat untuk bertambat, meskipun rute perjalanan yang dituju dapat dilalui oleh alat transportasi lain. Hal tersebut dapat terjadi mengingat jumlah barang yang dapat diangkut oleh kapal lebih banyak dibandingkan dengan jumlah barang yang dapat diangkut oleh armada lain.

Aktivitas pelabuhan di Indonesia selama ini masih didominasi di Pelabuhan Tanjung Priuk, sehingga membuat lalu lintas di Pelabuhan Tanjung Priuk sering mengalami kepadatan dan arus lalu lintas kendaraan khususnya ruas antara Bekasi-Tanjung Priok, Jakarta selalu mengalami kemacetan sehingga membuat biaya logistik perusahaan yang menggunakan jasa pelabuhan Tanjung Priuk menjadi tinggi. Dengan alasan itu pemerintah membangunan Pelabuhan Patimban yang berlokasi di Kabupaten Subang. Purnomo (2019) dalam Azka (2019) mengatakan tujuan pembangunan Pelabuhan Patimban yakni mengurangi biaya logistik, memperkuat ketahanan ekonomi, mengurangi tingkat kepadatan lalu lintas di Jakarta, serta menjamin keselamatan pelayaran termasuk area eksplorasi minyak dan gas.

Pembangunan Pelabuhan Patimban ditargetkan selesai pada tahun 2020. Adapun rencana pembangunan Pelabuhan Patimban meliputi pembangunan Car Terminal Pelabuhan Patimban direncanakan memiliki kapasitas tampung 250.000 sampai 300.000 kendaraan per tahun. Pelabuhan Patimban juga direncanakan akan melayani jenis muatan Peti Kemas dan Kendaraan Bermotor yang diangkut menggunakan kapal-kapal berukuran besar. Pelabuhan Patimban juga akan didukung area sarana penunjang untuk mendukung efisiensi logistik dari dan ke Pelabuhan Patimban seluas $356 \mathrm{Ha}$.

Namun dalam pembangunan Pelabuhan Patimban terdapat pro dan kontra terhadap pembangunan pelabuhan tersebut khususnya masyarakat pesisir Kabupaten Subang, hal ini disebabkan karena mereka terkenah langsung dampak dari pembangunan tersebut. Pembangunan Pelabuhan Patimban sendiri tidak dipungkiri bahwa akan memberikan dampak positif dan negatif bagi perekonomian masyarakat pesisir. Sehingga perlu diketahui terkait dampak positif dan negatif dari sisi perekonomian masyarakat pesisir di Kabupaten Subang.

\subsection{Rumusan Masalah, Tujuan Kegiatan dan Rencana Pemecahan Masalah}

Adapun rumusan masalah yang diteliti yakni bagaimana kelayakan pembangunan Pelabuhan Patimban dari segi ekonomi bagi masyarakat pesisir? Sedangkan tujuan penelitian yang dilakukan yaitu ingin mengetahui kelayakan pembangunan Pelabuhan Patimban dari segi ekonomi bagi masyarakat pesisir. Sementara itu, rencana pemecahan dalam penelitian ini menggunakan cost-benefit analysis (CBA).

\subsection{Kerangka Pemikiran}

Pembangunan pelabuhan di berbagai daerah tidak terlepas dari masyarakat pro dan kontra terhadap pembangunan tersebut. Masyarakat yang pro terhadap pembangunan biasanya mengetahui manfaat atau keuntungan adanya pembangunan pelabuhan, sedangkan masyarakat yang kontra biasanya masyarakat tersebut tekenah dampak terhadap pembangunan pelabuhan. Hal yang sama juga terjadi di masyarakat pesisir yang berada di sekitar pembangunan Pelabuhan Patimban yang berada di Kabupaten Subang. Untuk itu diperlukan suatu identifikasi dan analisis guna mengetahui manfaat atau keuntungan (benefit) dan biaya atau kerugian (cost) terhadap pembangunan Pelabuhan Patimban terhadap masyarakat pesisir yang berada di sekitar Pembangunan Pelabuhan Patimban. Sehingga terlihat jelas apakah pembangunan Pelabuhan Patimban lebih banyak kerugiannya dibandingkan keuntungan yang diraih, begitu juga sebaliknya.

Menurut Suherman dan Dault (2009), pembangunan pelabuhan khususnya pelabuhan perikanan nusantara (PPN) memberikan dampak positif maupun negatif bagi masyarakat. Dampak positif yaitu terjadinya peningkatan usaha dan terbukanya kesempatan kerja atau lapangan pekerjaan yang baru bagi masyarakat sekitar, dimana hal ini akan berpengaruh pada pendapatan. Sedangkan pengaruh negatif dari keberadaan pelabuhan yaitu terjadinya persaingan usaha, konflik sosial dan ketersediaan sumberdaya ikan yang semakin berkurang. Berikut ini adalah kerangka pemikiran dalam penelitian ini. Gambar 1 berikut ini adalah kerangka pemikiran dalam penelitian ini. 


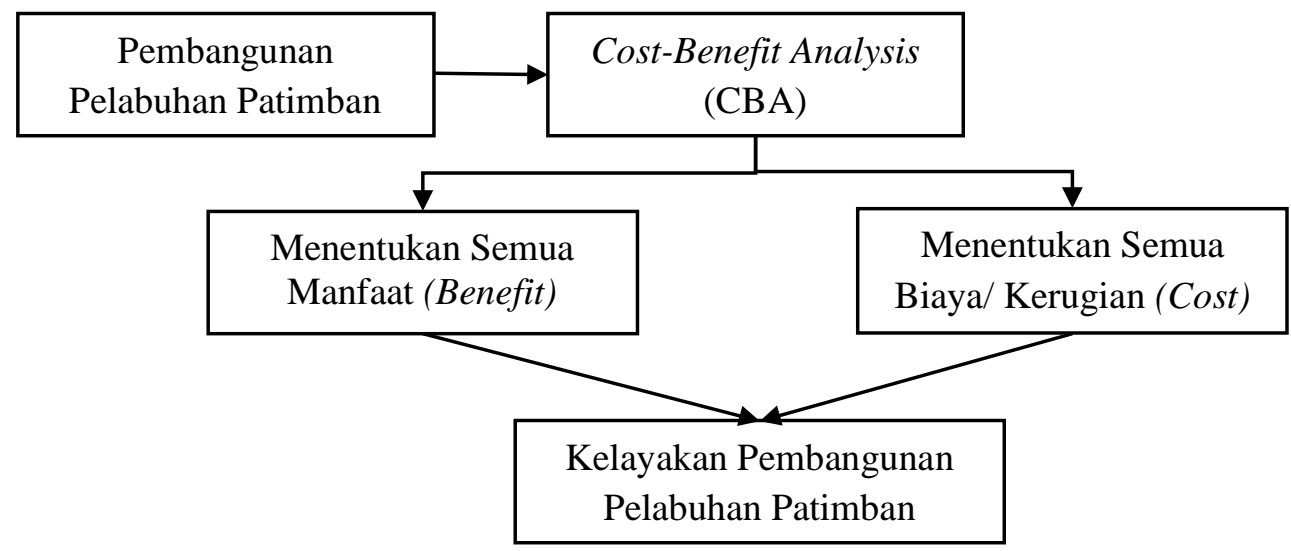

Sumber: Hasil Analisis, Tahun 2019

Gambar 1. Kerangka Pemikiran

\subsection{Tinjauan Pustaka}

Menurut Peraturan Menteri Perhubungan Republik Indonesia Nomor: PM 51 Tahun 2015 Tentang Penyelenggaraan Pelabuhan Laut, pelabuhan adalah tempat yang terdiri atas daratan dan/atau perairan dengan batas-batas tertentu sebagai tempat kegiatan pemerintahan dan kegiatan pengusahaan yang dipergunakan sebagai tempat kapal bersandar, naik turun penumpang, dan/atau bongkar muât barang, berupa terminal dan tempat berlabuh kapal yang dilengkapi dengan fasilitas keselamatan dan keamanan pelayaran dan kegiatan penunjang pelabuhan serta sebagai tempat perpindahan intra-dan antarmoda transportasi.

Kebijakan dari pemerintah terkait dengan pembangunan pelabuhan memberikan dampak perubahan sosial ekonomi bagi masyarakat pesisir sekitar. Dampak perubahan yang dialami oleh masyarakat pesisir sekitar adalah adanya perubahan fisik sarana dan prasarana pelabuhan yang lebih baik dari sebelumnya. Perubahan yang lain adalah dengan adanya penyerapan tenaga kerja dari usaha masyarakat dan peningkatan jumlah pendapatan bila dibandingkan dengan sebelum adanya kebijakan tersebut (Anton S et al., 2014).

Berdasarkan hasil penelitian yang dilakukan oleh Yusuf, et al. (2005), berbagai kelompok masyarakat berdasarkan mata pencaharian utama (nelayan, pedagang, buruh, pengolah dan petani) menyatakan bahwa pembangunan pelabuhan mempunyai dampak positif terhadap penyerapan tenaga kerja dan peningkatan pendapatan masyarakat sekitarnya. Sementara itu pengembangan dan pembangunan pelabuhan perikanan/ pangkalan pendaratan ikan dapat memajukan ekonomi di suatu wilayah dan sekaligus dapat meningkatkan penerimaan negara dan Pendapatan Asli Daerah. Direktorat Prasarana Perikanan Tangkap (2004) dalam Suherman dan Dault (2009).

\section{METODE PENELITIAN}

\subsection{Lokasi Penelitian}

Lokasi penelitian yang dilakukan bertempat di Pelabuhan Patimban yang terletak di Desa Patimban, Kecamatan Pusakanagara, Kabupaten Subang.

\subsection{Rancangan Kegiatan}

Rancangan kegiatan penelitian ini dimulai dengan melakukan identifikasi masalah dan melakukan tinjauan pustaka. Kemudian dilanjutkan dengan menentukan rumusan masalah dan tujuan penelitian serta membuat kerangka pemikiran yang didekati dari studi empirik dan studi pustaka. Setelah itu menentukan metode penelitian yang digunakan untuk menjawab tujuan penelitian yang dilanjutkan dengan pengumpulan data dan pengolahan data serta melakukan analisis data. Tahap terakhir, membuat kesimpulan terkait hasil penelitian yang telah dilakukan. Adapun kerangka rancangan kegiatan yang akan dilakukan dalam penelitian ini terlihat pada gambar 2 berikut. 


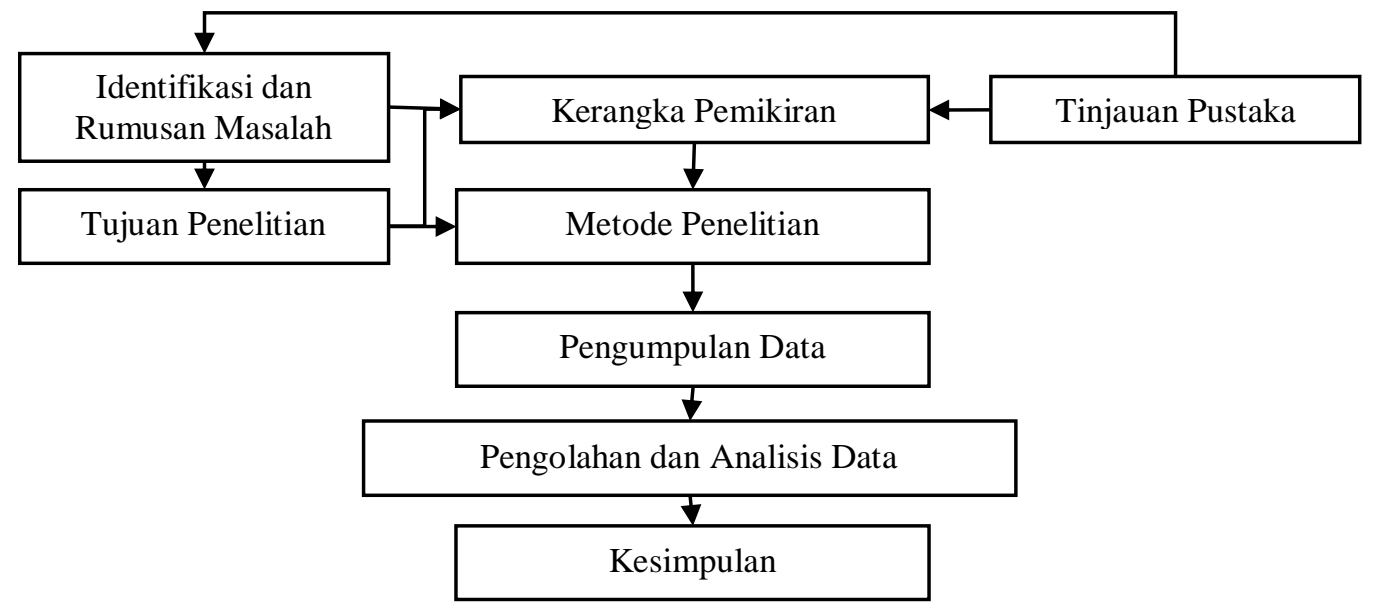

Sumber: Hasil Analisis, Tahun 2019

Gambar 2. Rancangan Kegiatan

\subsection{Teknik Pengumpulan Data}

Jenis data yang digunakan merupakan data primer karena kebutuhan informasi yang ada di data sekunder yang berkaitan dengan penelitian yang dilakukan belum tersedia, sehingga penulis menggali informasi ke lapangan. Teknik pengumpulan data menggunakan observasi dan wawancara yang dibantu dengan kuesioner. Observasi bertujuan untuk melakukan pengamatan secara langsung terhadap aktivitas para pelaku usaha dan nelayan di sekitar pembangunan Pelabuhan Patimban. Sedangkan wawancara bertujuan untuk menanyakan langsung kepada responden terkait dengan kebutuhan data yang diperlukan dalam penelitian ini. Wawancara dilakukan kepada responden yang terkenah dampak adanya pembangunan Pelabuhan Patimban. Responden dalam penelitian ini yaitu masyarakat pesisir di sekitar pembangunan pelabuhan Patimban dan Badan Perencanaan Pembangunan Daerah (Bappeda) Kabupaten Subang selaku instansi yang ikut berperan dalam pembangunan Pelabuhan Patimban.

\subsection{Populasi dan Sampel}

Populasi dalam penelitian ini adalah seluruh masyarakat yang terkenah dampak pembangunan Pelabuhan Patimban. Sementara itu, metode penarikan sampel dalam penelitian ini menggunakan judgement sampling. Hal ini disebabkan karena peneliti ingin memilih sampel berdasarkan penilaian terhadap beberapa karakteristik anggota sampel yang disesuaikan dengan maksud penelitian. Dengan demikian metode ini memperbolehkan peneliti memilih sampel dan menentukan banyaknya sampel yang diperlukan untuk memenuhi tujuannya.

\subsection{Teknis Analisis Data}

Teknis analisis yang digunakan dalam penelitian ini yaitu menggunakan cost-benefit analysis (CBA). Menurut Rahmiyati, et al. (2018), CBA digunakan untuk proses identifikasi, pengukuran dan perbandingan sosial manfaat dan biaya proyek atau program investasi dalam mengevaluasi penggunaan sumber daya ekonomi yang langka agar dapat digunakan secara efisien. Cost benefit analysis pada penelitian ini adalah analisis yang membandingkan antara biaya (cost) yang mencerminkan kerugian atau kehilangan penghasilan masyarakat pesisir adanya pembangunan Pelabuhan Patimban dengan output atau keuntungan (benefit) ekonomi masyarakat pesisir dari adanya pembangunan Pelabuhan Patimban. Adapun rumus CBA yaitu CBA = cost / benefit. Jika angka benefit diatas 1, maka pembangunan Pelabuhan Patimban di Kabupaten Subang layak untuk dilanjutkan karena biaya atau kerugian lebih kecil dibandingkan keuntungan. Namun sebaliknya jika hasil perhitungan kurang dari 1, maka pembangunan Pelabuhan Patimban di Kabupaten Subang layak untuk dilanjutkan. Hal ini disebabkan karena biaya atau kerugian lebih besar dibandingkan keuntungan.

Adapun indikator yang dianggap sebagai keuntungan (benefit) yang diperoleh adanya pembangunan Pelabuhan Patimban yaitu:

1. Penyerapan tenaga kerja lokal/masyarakat pesisir.

2. Penerimaan upah/gaji yang diterima oleh pekerja lokal/masyarakat pesisir. 
3. Multiplier effect konsumsi dan tabungan akibat gaji yang dibelanjakan oleh masyarakat pesisir.

4. Pajak penghasilan yang diterima oleh pemerintah.

Sedangkan indikator yang dianggap sebagai kerugian (cost) adanya pembangunan Pelabuhan Patimban yaitu:

1. Hilangnya penghasilan para pelaku usaha (usaha pertanian, perkebunan, tambak, nelayan, peternakan, perdagangan dan usaha pengeringan ikan) akibat penggunaan lahan darat.

2. Menurunnya penghasilan nelayan akibat adanya reklamasi.

Adapun rancangan kegiatan dalam penelitian ini dapat dilihat pada gambar berikut ini.

\section{HASIL DAN PEMBAHASAN}

\subsection{Kerugian Yang Timbul Akibat Pembangunan Pelabuhan Patimban (Cost)}

A. Penghasilan usaha pertanian, perkebunan, tambak, nelayan, peternakan, perdagangan dan usaha pengeringan ikan yang terkenah dampak pembangunan Pelabuhan Patimban

Adanya rencana pembangunan Pelabuhan Patimban di Kabupaten Subang, akan memiliki multiplier effect salah satunya penurunan penghasilan pada usaha pertanian, perkebunan, tambak, nelayan, peternakan, perdagangan dan usaha pengeringan ikan. Hal ini disebabkan karena lahan yang digunakan untuk usaha berbagai bidang usaha tersebut digunakan untuk pembangunan Pelabuhan Patimban. Selain itu, dengan adanya lalu lintas kapal yang bersandar maupun berangkat dari pelabuhan Patimban ke pelabuhan lain akan menyebabkan berbagai jenis ikan di perairan pesisir Kabupaten Subang akan berpindah ke daerah lain, karena terganggunya ekosistem laut.

Berdasakan hasil diskusi dengan Bappeda Kabupaten Subang bahwa luas lahan darat yang digunakan oleh pembangunan Pelabuhan Patimban diperkirakan menggunakan lahan darat seluas 250 Ha. Begitu juga dengan besaran asumsi yang digunakan merupakan hasil wawancara dengan Bappeda Kabupaten Subang. Berikut ini adalah rincian perkiraan penggunaan lahan darat yang terkenah dampak pembangunan Pelabuhan Patimban yakni lahan pertanian sawah yang terkenah dampak pembangunan Pelabuhan Patimban diperkirakan seluas 117,5 ha (47 persen), lahan perikanan tambak diperkirakan seluas 100 ha (40 persen), lahan perkebunan diperkirakan seluas 12,5 ha (5 persen), lahan perdagangan diperkirakan seluas 12,5 ha (5 persen), lahan peternakan diperkirakan seluas 5 ha ( 2 persen), dan lahan pengeringan ikan diperkirakan seluas 2,5 ha (1 persen).

Lahan yang digunakan untuk pembangunan Pelabuhan Patimban di Kabupaten Subang tentunya akan berdampak terhadap penurunan produksi pada masing-masing usaha di wilayah tersebut. Total produksi, banyaknya panen, dan harga rata-rata untuk produksi pada bidang usaha yang digunakan dalam perhitungan merupakan hasil wawancara dengan para responden. Tabel 3 ini adalah perhitungan total produksi per tahun untuk masing-masing usaha yang terkenah dampak pembangunan Pelabuhan Patimban.

Tabel 3. Perhitungan Penghasilan Usaha Pertanian Sawah, Perikanan Tambak, Perkebunan, Perdagangan, Peternakan, dan Pengeringan Ikan

\begin{tabular}{|l|r|c|r|r|r|r|r|}
\hline \multicolumn{1}{|c|}{ Produksi } & $\begin{array}{c}\text { Produksi/ } \\
\text { panen/Ha }\end{array}$ & Satuan & $\begin{array}{c}\text { Total } \\
\text { Produksi// } \\
\text { panen }\end{array}$ & $\begin{array}{c}\text { Banyaknya } \\
\text { Panen/ } \\
\text { tahun } \\
\text { (kali) }\end{array}$ & $\begin{array}{c}\text { Total } \\
\text { Produksi/ } \\
\text { tahun }\end{array}$ & $\begin{array}{c}\text { Harga } \\
\text { Rata-Rata } \\
\text { (Rp) }\end{array}$ & $\begin{array}{c}\text { Total } \\
\text { Penghasilan/ } \\
\text { tahun } \\
\text { (Rp000) }\end{array}$ \\
\hline $\begin{array}{l}\text { Pertanian } \\
\text { Padi }\end{array}$ & 6.000 & $\mathrm{~kg}$ & 705.000 & 2 & 1.410 .000 & 3.500 & 4.935 .000 \\
\hline $\begin{array}{l}\text { Perikanan } \\
\text { Tambak }\end{array}$ & 3.000 & $\mathrm{~kg}$ & 300.000 & 3 & 900.000 & 70.000 & 63.000 .000 \\
\hline Perkebunan & & & & & & & \\
\hline - Mangga & 750 & $\mathrm{~kg}$ & 2.813 & 2 & 5.625 & 5.000 & 28.125 \\
\hline - Pepaya & 1.750 & $\mathrm{~kg}$ & 4.375 & 4 & 17.500 & 3.500 & 61.250 \\
\hline - Pisang & 1.250 & $\mathrm{~kg}$ & 5.469 & 4 & 21.875 & 4.000 & 87.500 \\
\hline - Kelapa & 1.500 & $\mathrm{Buah}$ & 2.813 & 6 & 16.875 & 2.500 & $42.187,5$ \\
\hline Perdagangan & 5.000 .000 & $\mathrm{Rp}$ & 62.500 .000 & 12 & 750.000 .000 & & 750.000 \\
\hline Peternakan & & $\mathrm{ton}$ & & & & & \\
\hline
\end{tabular}




\begin{tabular}{|l|r|c|r|r|r|r|r|}
\hline Produksi & $\begin{array}{c}\text { Produksi/ } \\
\text { panen/Ha }\end{array}$ & Satuan & $\begin{array}{c}\text { Total } \\
\text { Produksi/ } \\
\text { panen }\end{array}$ & $\begin{array}{c}\text { Banyaknya } \\
\text { Panen/ } \\
\text { tahun } \\
\text { (kali) }\end{array}$ & $\begin{array}{c}\text { Total } \\
\text { Produksi/ } \\
\text { tahun }\end{array}$ & $\begin{array}{c}\text { Harga } \\
\text { Rata-Rata } \\
\text { (Rp) }\end{array}$ & $\begin{array}{c}\text { Total } \\
\text { Penghasilan/ } \\
\text { tahun } \\
\text { (Rp000) }\end{array}$ \\
\hline - Domba & 200 & ekor & 600 & 2 & 1.200 & 1.500 .000 & 1.800 .000 \\
\hline - Ayam & 3.000 & ekor & 6.000 & 6 & 36.000 & 35.000 & 1.260 .000 \\
\hline $\begin{array}{l}\text { Pengeringan } \\
\text { Ikan }\end{array}$ & 2.000 & kg & 5.000 & 48 & 240.000 & 20.000 & 4.800 .000 \\
\hline \multicolumn{19}{|c|}{} \\
\hline
\end{tabular}

Sumber: Data Primer Diolah, Tahun 2019

Berdasarkan tabel diatas, dapat dijelaskan bahwa total produksi per tahun untuk usaha pertanian sawah sebanyak $1.410 .000 \mathrm{~kg}$, perikanan tambak sebanyak $900.000 \mathrm{~kg}$, perkebunan manga sebanyak $5.625 \mathrm{~kg}$, perkebunan papaya sebanyak $17.500 \mathrm{~kg}$, perkebunan pisang sebanyak $21.875 \mathrm{~kg}$, dan perkebunan kelapa sebanyak 16.875 buah, perdagangan sebanyak Rp750.000.000,00, peternakan domba sebanyak 1.200 ekor, peternakan ayam sebanyak 36.000 ekor, dan pengeringan ikan sebanyak 240.000 ekor.

Berkaitan dengan perhitungan total penghasilan usaha yang terkenah dampak pembangunan Pelabuhan Patimban, maka total penghasilan usaha seluruh usaha sebesar Rp76.764.062.500,00/tahun dengan rincian penghasilan usaha pertanian sawah sebesar Rp4.935.000.000,00/tahun, usaha perikanan tambak sebesar Rp63.000.000.000,00/tahun, usaha perkebunan sebesar Rp219.062.500,00/tahun, usaha perdagangan sebesar Rp750.000.000,00/tahun, usaha peternakan domba sebesar Rp1.800.0000.000,00/tahun, usaha peternakan ayam sebesar Rp1.260.000.000,00/tahun, dan usaha pengeringan ikan sebesar Rp4.800.000.000,00/tahun.

\section{B. Penghasilan nelayan sebelum ada reklamasi dan setelah ada reklamasi terkait pembangunan Pelabuhan Patimban}

Dengan adanya pembangunan Pelabuhan Patimban tidak hanya berdampak terhadap pendapatan para pelaku usaha yang akan hilang akibat lahan usaha terkenah pembangunan, namun juga harus diperhatikan dampak dari adanya reklamasi wilayah pesisir. Reklamasi merupakan proses membuat daratan baru pada daerah perairan/pesisir pantai atau daerah rawa. Reklamasi biasanya terjadi karena semakin tingginya tingkat populasi manusia di daerah pesisir sehingga lahan untuk pembangunan semakin sempit ataupun untuk mengurangi penggunaan lahan daratan karena suatu proses pembangunan khususnya di kawasan pesisir yang bertujuan untuk mengurangi resiko penggunaan lahan darat yang dapat menyebabkan dampak yang besar bagi perekonomian daerah sekitar. Untuk itu, maka dapat dihitung biaya sosial yang merupakan dampak dari adanya reklamasi.

Rencana reklamasi pantai dipastikan akan berdampak terhadap penghasilan yang diterima oleh Nelayan ataupun bisa jadi nelayan akan kehilangan mata pencahariannya karena terganggunya biota laut dan tingginya aktivitas lalu lintas kapal yang akan berlabuh ataupun berangkat dari Pelabuhan Patimban. Berdasarkan hasil diskusi dengan Bappeda Kabupaten Subang bahwa luas lahan untuk reklamasi untuk pembangunan Pelabuhan Patimban yakni seluas $300 \mathrm{Ha}$. Tabel 4 ini adalah perhitungan tangkapan ikan dan udang yang diperoleh oleh para nelayan sebelum ada reklamasi dan setelah ada reklamasi terkait pembangunan Pelabuhan Patimban.

Tabel 4. Perhitungan Total Tangkapan Nelayan Sebelum ada Reklamasi dan setelah ada Reklamasi Terkait Pembangunan Pelabuhan Patimban

\begin{tabular}{|l|c|c|c|c|c|c|}
\hline \multicolumn{1}{|c|}{ Keterangan } & $\begin{array}{c}\text { Hari } \\
\text { Melaut }\end{array}$ & $\begin{array}{c}\text { Hasil } \\
\text { Tangkapan } \\
\text { Rata-Rata (Kg) }\end{array}$ & $\begin{array}{c}\text { Banyaknya } \\
\text { Melaut } \\
\text { (Hari) }\end{array}$ & $\begin{array}{c}\text { Total } \\
\text { Produksi }\end{array}$ & $\begin{array}{c}\text { Harga } \\
\text { Rata- } \\
\text { Rata (Rp) }\end{array}$ & $\begin{array}{c}\text { Total } \\
\text { Penghasilan/ } \\
\text { Tahun (Rp) }\end{array}$ \\
\hline Udang & & & & & & \\
\hline $\begin{array}{l}\text { Sebelum Ada } \\
\text { Pembangunan } \\
\text { Pelabuhan }\end{array}$ & 1 Hari & 10 & 300 & 3.000 & 75.000 & 225.000 .000 \\
\hline
\end{tabular}




\begin{tabular}{|c|c|c|c|c|c|c|}
\hline Keterangan & $\begin{array}{c}\text { Hari } \\
\text { Melaut }\end{array}$ & $\begin{array}{c}\text { Hasil } \\
\text { Tangkapan } \\
\text { Rata-Rata }(\mathrm{Kg})\end{array}$ & $\begin{array}{c}\text { Banyaknya } \\
\text { Melaut } \\
\text { (Hari) }\end{array}$ & $\begin{array}{c}\text { Total } \\
\text { Produksi }\end{array}$ & $\begin{array}{c}\text { Harga } \\
\text { Rata- } \\
\text { Rata }(\mathbf{R p})\end{array}$ & $\begin{array}{c}\text { Total } \\
\text { Penghasilan/ } \\
\text { Tahun }(\mathbf{R p})\end{array}$ \\
\hline $\begin{array}{ll}\text { Setelah } & \text { Ada } \\
\text { Pembangunan } & \\
\text { Pelabuhan } & \\
\text { (Reklamasi) } & \\
\end{array}$ & 1 Hari & 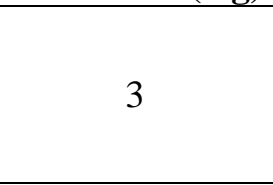 & 300 & 900 & 75.000 & 67.500 .000 \\
\hline \multicolumn{7}{|l|}{ Ikan } \\
\hline $\begin{array}{ll}\text { Sebelum } & \text { Ada } \\
\text { Pembangunan } & \\
\text { Pelabuhan } & \end{array}$ & 1 Hari & 250 & 300 & 75.000 & 4.000 & 300.000 .000 \\
\hline $\begin{array}{ll}\text { Setelah } & \text { Ada } \\
\text { Pembangunan } & \\
\text { Pelabuhan } & \\
\text { (Reklamasi) } & \\
\end{array}$ & 1 Hari & 100 & 300 & 30.000 & 4.000 & 120.000 .000 \\
\hline \multicolumn{6}{|c|}{ Total Penghasilan Nelayan Sebelum Ada Pembangunan Pelabuhan } & 525.000 .000 \\
\hline \multicolumn{6}{|c|}{ Total Penghasilan Nelayan Setelah Ada Pembangunan Pelabuhan (Reklamasi) } & 187.500.000 \\
\hline \multicolumn{6}{|c|}{$\begin{array}{ll} & \text { Total Penurunan }\end{array}$} & 337.500 .000 \\
\hline
\end{tabular}

Sumber: Data Primer Diolah, Tahun 2019

Berdasarkan tabel diatas, bahwa total tangkapan udang sebelum adanya reklamasi yakni sebanyak $3.000 \mathrm{~kg}$ sedangkan setelah adanya reklamasi mengalami penurunan menjadi $900 \mathrm{~kg}$ atau menurun sebesar $2.100 \mathrm{~kg}$. Sementara itu total tangkapan ikan sebelum adanya reklamasi yakni sebanyak $75.000 \mathrm{~kg}$ sedangkan setelah adanya reklamasi mengalami penurunan menjadi $30.000 \mathrm{~kg}$ atau menurun sebesar $45.000 \mathrm{~kg}$. Menurunnya total tangkapan udang dan ikan akibat adanya reklamasi untuk pembangunan Pelabuhan Patimban sehingga berdampak terhadap menurunnya penghasilan yang diterima oleh nelayan. Total penghasilan nelayan sebelum ada pembangunan Pelabuhan Patimban (sebelum reklamasi) sebesar Rp525.000.000,00/tahun, dan setelah adanya reklamasi guna pembangunan Pelabuhan Patimban, penghasilan para nelayan mengalami penurunan menjadi Rp187.500.000,00/tahun atau mengalami penurunan sebesar Rp337.500.000,00/tahun. Dengan demikian, kerugian yang timbul adanya pembangunan Pelabuhan Patimban di Kabupaten Subang yakni sebesar Rp77.101.562.500,00 yang terdiri dari penghasilan para pelaku usaha yang hilang karena penggunaan lahan darat sebesar Rp76.764.062.500,00 dan penghasilan nelayan yang hilang karena reklamasi sebesar Rp337.500.000,00.

\subsection{Keuntungan Yang Timbul Akibat Pembangunan Pelabuhan Patimban}

\section{A. Penyerapan Tenaga Kerja dan Pembentukan Pendapatan/Gaji}

Dengan adanya pembangunan Pelabuhan Patimban akan berdampak terhadap pembentukan pendapatan/gaji yang diterima oleh masyarakat yang bekerja di Pelabuhan Patimban khususnya masyarakat pesisir di wilayah Kabupaten Subang. Hal ini disebabkan karena dengan adanya pembangunan Pelabuhan Patimban akan terbukanya lapangan pekerjaan bagi masyarakat baik masyarakat sekitar maupun pendatang. Masyarakat sekitar pembangunan Pelabuhan Patimban dapat bekerja di tenaga kerja bongkar muat (TKBM), karena tenaga kerja yang bekerja sebagai tenaga bongkar muat tidak harus memiliki pendidikan tinggi. Hal ini sesuai dengan pendidikan masyarakat pesisir Kabupaten Subang yang berada di sekitar pembangunan Pelabuhan Patimban yakni rata-rata berpendidikan rendah. Hal ini identik bahwa pendidikan masyarakat pesisir mayoritas berpendidikan masih rendah. Hal senada juga dikemukakan oleh hasil penelitian Febria (2017), bahwa pendidikan masyarakat pesisir yang bekerja petani tambak dan berwiraswasta mayoritas hanya lulusan SD dan SMP. Sementara itu masyarakat yang bekerja sebagai buruh memiliki kualifikasi tingkat pendidikan yaitu SMP dan SMA, namun tidak menutup kemungkinan untuk lulusan SD karena adanya pelatihan khusus sebelum bekerja.

Dalam pembangunan Pelabuhan Patimban, rencana lahan yang digunakan yaitu seluas $550 \mathrm{Ha}$, dengan rincian 250 Ha menggunakan lahan darat, dan $300 \mathrm{Ha}$ menggunakan reklamasi laut. Untuk mendukung penelitian ini, dilakukan benchmark terhadap Pelabuhan Tanjung Priuk, karena Pelabuhan 
Patimban digadang-gadang sebagai pelabuhan alternatif Pelabuhan Tanjung Priuk yang sudah mengalami kelebihan kapasitas. Menurut Arifin (2019), bahwa tenaga kerja bongkar muat (TKBM) di Tanjung Priuk Tahun 2019 sebanyak 2.400 TKBM, sedangkan Pelabuhan Tanjung Priuk memiliki luas lahan yakni 604 Ha. Dengan demikian dapat dikatakan bahwa 1 Ha di Pelabuhan Tanjung Priuk mampu menyerap sekitar 4 tenaga kerja bongkar muat (TKBM). Informasi tersebut juga dapat digunakan di Pelabuhan Patimban, karena Pelabuhan Patimban akan dibangun sebagai pelabuhan alternatif jika Tanjung Priuk mengalami kelebihan kapasitas sehingga desain pembangunan pelabuhan tidak jauh berbeda antar keduanya. Namun berdasarkan informasi yang berkembang bahwa Pelabuhan Patimban didesain lebih bagus dibandingkan Pelabuhan Tanjung Priuk. Adapun rincian mengenai besaran jumlah kebutuhan tenaga kerja bongkar muat di Pelabuhan Patimban dapat dilihat pada tabel 5 berikut.

Tabel 5. Perhitungan Kebutuhan Tenaga Kerja dan Besaran Upah Yang Diterima Terhadap Adanya Pembangunan Pelabuhan Patimban

\begin{tabular}{|l|r|c|}
\hline \multicolumn{1}{|c|}{ Komponen } & \multicolumn{1}{c|}{ Jumlah } & Satuan \\
\hline 1 Ha Lahan Pelabuhan & 4 & Orang \\
\hline Luas Pelabuhan Patimban & 550 & Ha \\
\hline Total Tenaga Kerja Kerja Bongkar Muat (TKBM) & 2.200 & Orang \\
\hline Besaran Upah & 190.000 & Orang \\
\hline Besaran Upah & 5.700 .000 & Orang/Bulan (Rp) \\
\hline Total Besaran Upah/Bulan & 418.000 .000 & Rp \\
\hline Total Besaran Upah/Tahun & 5.016 .000 .000 & RP \\
\hline
\end{tabular}

Sumber: Data Primer Diolah, Tahun 2019

Dari tabel diatas dapat diketahui bahwa akan terbukanya lapangan pekerjaan bagi 2.200 orang yang bekerja sebagai tenaga kerja bongkar muat. Jumlah tersebut tidak mengikutsertakan masyarakat sekitar yang bekerja sebagai manajer dan karyawan yang bekerja di Pelabuhan. Banyaknya masyarakat pesisir yang akan berkerja di wilayah Pelabuhan Patimban tentunya juga akan membentuk pendapatan/gaji yang diakibatkan dari adanya pendapatan yang diterima oleh masing-masing pekerja. Menurut informasi dari PT. Indo Primer Sekuritas (2019), bahwa upah tenaga kerja bongka muat (TKBM) sebesar Rp190.000,00/orang. Kesepakatan tersebut ditandatangani Asosiasi Perusahaan Bongkar Muat Indonesia (APBMI) DKI Jakarta, DPW Asosiasi Logistik dan Forwarder Indonesia (ALFI) DKI Jakarta, Gabungan Importir Nasional Seluruh Indonesia (GINSI) DKI, DPC Indonesia National Shipowners Association (INSA) Jaya, dan disaksikan Manajemen PT.Pelindo II Tanjung Priok dan Kantor Otoritas Pelabuhan Tanjung Priok. Besaran gaji yang diterima oleh semua tenaga kerja bongkar muat (TKBM) dalam setahun yaitu sebesar Rp5.016.000.000.000,00.

\section{B. Multiplier Effect Konsumsi dan Tabungan}

Dengan terbentuknya pendapatan/gaji yang diterima oleh para tenaga kerja tentunya akan menimbulkan multiplier effect konsumsi dan multiplier effect tabungan yang diakibatkan dari adanya pendapatan yang diterima oleh masing-masing pekerja. Tabel 6 berikut ini adalah ilustrasi perhitungan multiplier effect konsumsi dan multiplier effect tabungan dari adanya Pembangunan Pelabuhan Patimban.

Tabel 6. Perhitungan Multiplier Effect Konsumsi dan Multiplier Effect Tabungan Terhadap Adanya Pembangunan Pelabuhan Patimban

\begin{tabular}{|c|c|c|c|c|c|c|c|}
\hline \multicolumn{2}{|c|}{$\begin{array}{c}\text { Besaran Konsumsi } \\
(\mathbf{9 0 \%})\end{array}$} & \multicolumn{2}{c|}{$\begin{array}{c}\text { Besaran Tabungan } \\
(\mathbf{1 0 \%})\end{array}$} & \multicolumn{2}{c|}{$\begin{array}{c}\text { Multiplier Effect } \\
\text { Konsumsi }\end{array}$} & \multicolumn{2}{c|}{$\begin{array}{c}\text { Multiplier Effect } \\
\text { Tabungan }\end{array}$} \\
\hline $\begin{array}{c}\text { Pertahun } \\
(\mathbf{R p})\end{array}$ & Total (Rp) & $\begin{array}{c}\text { Pertahun } \\
(\mathbf{R p})\end{array}$ & Total (Rp) & $\begin{array}{c}\text { Pertahun } \\
(\mathbf{R p})\end{array}$ & Total (Rp) & $\begin{array}{c}\text { Pertahun } \\
(\mathbf{R p})\end{array}$ & $\begin{array}{c}\text { Total } \\
(\mathbf{R p})\end{array}$ \\
\hline 171.000 & 376.200 .000 & 19.000 & 41.800 .000 & 153.900 & 338.580 .000 & 1.900 & 4.180 .000 \\
\hline
\end{tabular}

Sumber: Data Primer Diolah, Tahun 2019 
Berdasarkan perhitungan diatas, penghasilan/gaji yang diterima oleh TKBM diperkirakan tidak dibelanjakan seluruhnya untuk konsumsi, namun sebagian untuk ditabung guna berjaga-jaga untuk memenuhi kebutuhan dikemudian hari. Diasumsikan untuk persentase besaran konsumsi sebesar 90\%, sedangkan persentase besaran tabungan sebesar $10 \%$. Besaran multiplier effect dan tabungan sebesar Rp342.760.000,00.

\section{Penerimaan Pajak Penghasilan}

Selain memberikan dampak bagi individu, pembangunan Pelabuhan Patimban juga berdampak pada daerah tempat dibangunnya kawasan industri tersebut, dalam hal ini adalah Kabupaten Subang. Salah satu dampak dari adanya pembangunan Pelabuhan Patimban yang secara langsung terhadap Kabupaten Subang yaitu adanya penerimaan dari sisi pajak penghasilan (PPh). Dengan mengacu kepada Pasal 17 ayat 1, Undang-Undang No. 36 tahun 2008 (Undang-Undang tentang Pajak Penghasilan), maka potensi pajak penghasilan pribadi dari para tenaga kerja yang bekerja di Pelabuhan Patimban dengan asumsi mengacu kepada Peraturan Menteri Keuangan No. 122/PMK010/2015 tentang Penyesuaian Besarnya Penghasilan Tidak Kena Pajak (PTKP) untuk status pekerja yakni belum kawin sebesar Rp36.000.000,00, Kawin, anak 0 sebesar Rp39.000.000,00, Kawin, anak 1 sebesar Rp42.000.000,00, Kawin, anak 2 sebesar Rp45.000.000,00, dan Kawin, anak 3 sebesar Rp48.000.000,00.

Tabel 7 berikut ini adalah perhitungan potensi penerimaan pajak perorangan terkait adanya pembangunan Pelabuhan Patimban dengan asumsi bahwa tenaga kerja yang belum kawin diperkirakan sebesar 5\%, kawin dan belum punya anak sebanyak 15\%, kawin dan punya anak 1 sebesar 30\%, dan tenaga kerja yang kawin yang memiliki anak sebanyak 2 orang sebesar $50 \%$. Total potensi pajak penghasilan perorangan yang diterima adalah sebesar Rp2.821.500.000,00.

Tabel 7. Perhitungan Potensi Penerimaan Pajak Perorangan

\begin{tabular}{|c|c|c|c|c|c|c|}
\hline $\begin{array}{l}\text { Potensi PPh } \\
\text { perorangan }\end{array}$ & $\begin{array}{c}\text { Total } \\
\text { TKBM }\end{array}$ & $\begin{array}{c}\text { Total } \\
\text { Penghasilan } \\
\text { Pertahun } \\
(\mathbf{R p}) \\
\end{array}$ & $\begin{array}{c}\text { PTKP } \\
\text { (Rp) }\end{array}$ & PKP (Rp) & $\begin{array}{l}\text { Potensi PPh } \\
\text { Orang Pribadi } \\
\text { (Rp) }\end{array}$ & $\begin{array}{c}\text { Total Potensi } \\
\text { PPh Orang } \\
\text { Pribadi (Rp) }\end{array}$ \\
\hline Belum Kawin & 110 & 68.400 .000 & 36.000 .000 & 32.400 .000 & 1.620 .000 & 178.200 .000 \\
\hline Kawin, anak 0 & 330 & 68.400 .000 & 39.000 .000 & 29.400 .000 & 1.470 .000 & 485.100 .000 \\
\hline Kawin, anak 1 & 660 & 68.400 .000 & 42.000 .000 & 26.400 .000 & 1.320 .000 & 871.200 .000 \\
\hline Kawin, anak 2 & 1.100 & 68.400 .000 & 45.000 .000 & 23.400 .000 & 1.170 .000 & 1.287 .000 .000 \\
\hline \multicolumn{6}{|c|}{ Total } & 2.821 .500 .000 \\
\hline
\end{tabular}

Sumber: Data Primer Diolah, Tahun 2019

Dengan demikian, maka keuntungan (benefit) dalam satu tahun potensi penerimaan atau keuntungan yang dihasilkan dari adanya pembangunan Pelabuhan Patimban adalah sebesar Rp8.180.260.000,00 yang terdiri dari penerimaan gaji sebesar Rp5.016.000.000,00 multiplier effect konsumsi dan tabungan sebesar Rp342.760.000,00, dan PPh sebesar Rp2.821.500.000,00.

\subsection{Analisis Biaya (Cost) dan Keuntungan (Benefit) Pembangunan Pelabuhan Patimban}

Berdasarkan hasil perhitungan yang telah dilakukan bahwa kerugian yang timbul dari adanya pembangunan Pelabuhan Patimban yang merupakan refleksi dari biaya (cost) yakni sebesar Rp77.101.562.500,00, sedangkan keuntungan yang timbul dari adanya pembangunan Pelabuhan Patimban yang merupakan refleksi dari keuntungan (benefit) yakni sebesar Rp5.016.000.000,00. Dengan demikian bahwa pembangunan Patimban jika melihat dari kebermanfaatan terhadap masyarakat pesisir di Kabupaten Subang tidak layak untuk dilanjutkan. Namun jika ditelisik pada kebermanfaatan secara global bahwa pembangunan Pelabuhan Patimban memberikan efek yang besar bagi perkembangan ekonomi masyarakat sekitar, perekonomian daerah baik Kabupaten Subang maupun kabupaten tetangga yang merupakan imbas dari keberadaan Pelabuhan Patimban, serta perekonomian Indonesia. Hal ini terlihat dengan adanya pembangunan Pelabuhan Patimban tidak dipungkiri akan menyerap tenaga kerja tidak hanya dari sisi tenaga kerja bongkar muat TKBM, namun 
juga bisa menyerap tenaga kerja yang bekerja menjadi karyawan di Pelabuhan Patimban. Selain itu juga tentunya banyak perusahaan yang bermunculan di sekitar Pelabuhan Patimban seperti perusahaan pergudangan, perusahaan trucking, perusahaan freight, perusahaan asuransi, perusahaan kurir, perusahaan dan berbagai perusahaan lainnya yang mendukung aktivitas pelabuhan, logistik maupun perkapalan, dan perusahaan tersebut dipastikan akan membutuhkan tenaga kerja. Peluang masyarakat pesisir untuk bekerja di perusahaan-perusahaan tersebut pun sangat besar. Selain itu juga akan muncul usaha-usaha pendukung seperti rumah makan, penginapan, hotel, perbengkelan, dan berbagai usaha lainnya.

Dengan banyaknya tenaga kerja yang terserap akan berdampak terhadap peningkatan kesejahteraan masyarakat khususnya masyarakat pesisir yang sebelumnya hanya bekerja di bidang usaha dengan berpenghasilan rendah. Dengan adanya pembangunan Pelabuhan Patimban, masyarakat diharapkan nantinya akan berkerja pada bidang usaha yang memberikan penghasilan yang diberikan lebih besar dibandingkan usaha yang sebelumnya digeluti oleh masyarakat khususnya masyarakat pesisir. Hal senada juga disampaikan oleh Suherman dan Dault (2009), pembangunan pelabuhan khususnya pelabuhan perikanan nusantara (PPN) memberikan dampak positif maupun negatif bagi masyarakat. Dampak positif yaitu terjadinya peningkatan usaha dan terbukanya kesempatan kerja atau lapangan pekerjaan yang baru bagi masyarakat sekitar, dimana hal ini akan berpengaruh pada pendapatan. Sedangkan pengaruh negatif dari keberadaan pelabuhan yaitu terjadinya persaingan usaha, konflik sosial dan ketersediaan sumberdaya ikan yang semakin berkurang. Begitu juga menurut Yusliana dan Satlita (2017), bahwa Pembangunan PPI Logending berdampak terhadap tingkat kesejahteraan masyarakat dapat tercermin dengan terjadinya peningkatan usaha dan terbukanya kesempatan kerja atau lapangan pekerjaan baru bagi masyarakat sekitar, dimana hal ini akan berpengaruh pada pendapatan. Hal ini juga terlihat dari kondisi sebelum dan sesudah adanya PPI. Begitu juga dengan penelitian Febria (2017), bahwa. Dampak positif dari pembangunan Pelabuhan Kendal adalah meningkatkan pendapatan wiraswasta terutama pedagang dan membuka lapangan kerja baru.

Menurut penelitian dari Zulkifli (2017), bahwa hasil analisis data diketahui bahwa keberadaan Pelabuhan Bira mempengaruhi tingkat penghasilan warga, dimana pendapatan sebelumnya berada dalam kisaran Rp750.000,00 - Rp1.000.000,00 sedangkan setelah Pelabuhan Bira terbangun diperoleh data bahwa penghasilan warga mencapai Rp1.500.000,00 - Rp2.500.000,00, hal ini berbanding lurus dengan dampak sosial yang terjadi bahwa berdasarkan hasil survey dan wawancara, keberadaan Pelabuhan Bira mempengaruhi sosial ekonomi masyarakat baik dalam pendapatan, tingkat pendidikan, dan mata pencaharian, masyarakat yang diharapkan mampu memenuhi segala kebutuhan dan mencapai kesejahteraan bagi masyarakat di Desa Bira.

Pembangunan Pelabuhan Patimban tidak hanya berdampak pada masyarakat saja, namun juga berdampak pada pemerintah daerah. Hal ini sesuai yang dikemukakan oleh Direktorat Prasarana Perikanan Tangkap (2004) dalam Suherman dan Dault (2009), bahwa pengembangan dan pembangunan pelabuhan perikanan/ pangkalan pendaratan ikan dapat memajukan ekonomi di suatu wilayah dan sekaligus dapat meningkatkan penerimaan negara dan Pendapatan Asli Daerah.

\section{KESIMPULAN}

Pembangunan Pelabuhan Patimban di Kabupaten Subang memberikan dampak positif (keuntungan/benefit) maupun negatif (kerugian/cost) dari segi ekonomi bagi masyarakat khususnya masyarakat pesisir sekitar wilayah pembangunan pelabuhan. Berdasarkan hasil analisis dengan menggunakan CBA bahwa keuntungan yang dihasilkan lebih kecil dibandingkan dengan kerugian yang ditimbulkan adanya pembangunan Pelabuhan Patimban. Sehingga jika dampak pembangunan Pelabuhan Patimban hanya berfokus pada masyarakat pesisir, maka pembangunan tidak layak untuk dilaksanakan. Hal yang menyebabkan kecilnya nilai keuntungan yang diperoleh karena dalam penelitian ini hanya melakukan perhitungan terhadap penyerapan tenaga kerja dari masyarakat pesisir yang bekerja menjadi TKBM, tidak melakukan perhitungan penyerapan tenaga kerja secara menyeluruh seperti masyarakat yang menjadi karyawan di Pelabuhan, perusahaan pergudangan, perusahaan freight, perusahaan kurir, perusahaan trucking, rumah makan, penginapan, perbengkelan, dan berbagai perusahaan lainnya. Sehingga diperlukan penelitian lebih lanjut untuk menghitung seluruh keuntungan yang timbul dari penyerapan tenaga kerja yang bekerja di semua bidang usaha. Sedangkan kerugian adanya pembangunan Pelabuhan Patimban yaitu hilangnya penghasilan masyarakat akibat adanya penggunaan lahan darat dan reklamasi. 
Namun secara menyeluruh bahwa pembangunan Pelabuhan Patimban memberikan dampak besar bagi perkembangan ekonomi masyarakat pesisir, perekonomian daerah Kabupaten Subang, Kabupaten tetangga dan perekonomian Indonesia pada umumnya. Hal ini disebabkan karena tingginya permintaan terhadap tenaga kerja dari berbagai perusahaan dan pelabuhan, yang nantinya berdampak terhadap ekonomi masyarakat. Selain itu juga berdampak positif terhadap efisiensi perusahaan-perusahaan yang menggunakan pelabuhan dalam kegiatan ekspor maupun impor dan kemungkinan akan terciptanya kontrakan rumah, kostan, tempat makan, berbagai jenis warung, ataupun usaha lainnya yang dikelola langsung oleh masyarakat sekitar. Hal tersebut sesuai dengan penelitian terdahulu terkait penelitian pembangunan pelabuhan dan kondisi eksisting yang terjadi di wilayah sekitar Pelabuhan Tanjung Priuk. Untuk itu pemerintah harus merealisasikan dan mempercepat pembangunan Pelabuhan Patimban karena memberikan dampak yang signifikan bagi masyarakat khsusunya masyarakat pesisir Kabupaten Subang, dan masyarakat juga harus mampu menangkap peluang adanya pelabuhan Patimban salah satunya dengan cara meningkatkan kemampuan, pendidikan dan inovasi terhadap usaha-usaha yang dibutuhkan dengan adanya aktivitas pelabuhan Patimban.

Adapun rekomendasi untuk peneliti selanjutnya yang akan melakukan penelitian yang sama maka diharapkan memperkaya atau menggali berbagai kriteria untuk menghitung CBA sehingga perhitungan semakin detail khususnya terkait dengan hal-hal yang bisa menambah pemasukan dari adanya pembangunan Pelabuhan Patimban. Salah satunya bisa menjelaskan secara kuantitatif dampak dari pembangunan Pelabuhan Patimban yang belum dihitung dalam penelitian ini. Sementara itu, rekomendasi untuk pemerintah baik pusat maupun daerah diharapkan mempercepat pembangunan Pelabuhan Patimban karena memberikan dampak yang besar bagi perekonomian khususnya aktivitas logistik dan transportasi. Sedangkan masyarakat dan para pelaku usaha diharapkan mampu menangkap potensi keuntungan terkait dengan keberadaan adanya pembangunan Pelabuhan Patimban.

\section{REFERENSI}

Anton S. M., Mardiyono \& Prasetya, W. Y. (2014). Evaluasi Dampak Kebijakan Pembangunan Pelabuhan Perikanan Pantai (PPP) Tamperan Terhadap Perubahan Sosial Ekonomi Masyarakat Pesisir Sekitar (Studi Kasus pada PPP Tamperan Kab. Pacitan). Jurnal Administrasi Publik (JAP), 2(11), 1010-1015.

Arifin, C. (2019). Koperasi TKBM Priok Siap Tingkatan Kerjasam dengan TPK Koja. Tibunbisnis. Jakarta. Dapat diliat pada https://www.tribunnews.com/bisnis/2019/07/19/koperasi-tkbm-prioksiap-tingkatkan-kerjasama-dengan-tpk-koja

Azka, R., M. (2019). Pembangunan Pelabuhan Patimban Baru 29\%. Ekonomi Bisnis. Jakarta. Dapat dilihat pada https://ekonomi.bisnis.com/read/20190624/98/936935/pembangunan-pelabuhanpatimban-baru-29.

Febria, A. (2017). Dampak Pembangunan Pelabuhan Pada Pemanfaatan Lahan di Pelabuhan Kendal Kabupaten Kendal. Jurnal Departemen Pembangunan Wilayah Universitas Gajah Mada Yogyakarta, 1-14.

Menteri Perhubungan Republik Indonesia. (2015). Peraturan Menteri Perhubungan Republik Indonesia Nomor: PM 51 Tahun 2015 Tentang Penyelenggaraan Pelabuhan Laut. Kementrian Perhubungan. Jakarta.

PT. Indo Primer Sekuritas. (2018). Tarif Bongkar Muat Kargo Priok Naik 5\% - 20\% Mulai 1 Oktober. Jakarta. Dapat diliat pada https://www.indopremier.com/ipotnews/newsDetail.php?jdl=Tarif_Bongkar_Muat_Kargo_Prio k_Naik_5\%_20\%_Mulai_1_Oktober\&news_id=343435\&group_news=RESEARCHNEWS\& news_date $=\&$ taging_subtype $=$ INDONESIA\&name $=\& \operatorname{search}=y \_$general $\& q=I N D O N E S I A, \% 20$ \&halaman $=1$.

Rahmiyati, A. L., Abdillah, A. D., Susilowati, \& Anggaraini, D. (2018). Cost Benefit Analysis (CBA) Program Pemberian Makanan Tambahan (PMT) Susu Pada Karyawan di PT. Trisula Textile Industries Tbk Cimahi Tahun 2018. Jurnal Ekonomi Kesehatan Indonesia, 3(1), 125-134.

Suherman, A. dan Dault, A. (2019). Dampak Sosial Ekonomi Pembangunan dan Pengembangan Pelabuhan Perikanan Nusantara (PPN) Pengambengan Jembrana Bali. Jurnal Saintek Perikanan, 4(2), 24-32. 
Yusliana dan Satlita, L. (2017). Dampak Pembanugunan Pelabuhan Pendaratan Ikan Logending Terhadap Kesejahteraan Masyarakat Desa Ayah Kecamatan Ayah Kabupaten Kebumen. Adinegara. Jurnal Mahasiswa Ilmu Administrasi Negara, 6(3), 310-319.

Yusuf, H., Moedikdjo, K., Saeni, M. S., \& Nasution, L. I. (2015). Dampak Pembangunan Pelabuhan Perikanan Terhadap Penyerapan Tenaga Kerja Dan Pendapatan Masyarakat (Studi Kasus di Pelabuhan Perikanan Lempasing, Bandar Lampung). Buletin Ekonomi Perikanan, 6(1), 57-64.

Zulkifli, A. (2017). Pengaruh Pelabuhan Bira Terhadap Sosial Ekonomi Masyarakat Desa Bira Kecamatan Bontobahari Kabupaten Bulukumba. Jurusan Teknik Perencanaan Wilayah Dan Kota Fakultas Sains Dan Teknologi Universitas Islam Negeri Alauddin Makassar. 